\title{
Empat Koreografer Tari Kontemporer Indonesia Periode 1990-2008
}

\author{
Eko Supriyanto, Timbul Haryono, R. M. Soedarsono, Sal Murgiyanto \\ Universitas Gadjah Mada (UGM) Yogyakarta \\ Jl. Bulaksumur, Yogyakarta 55281
}

\begin{abstract}
This research will elaborate four Indonesian contemporary choreographers, which lead to open the significant of embodiment process on Indonesian dancers. With a focus on four choreographers, Martinus Miroto, Mugiyono Kasido, Hartati, and Jecko Siompo. A case study of body of those four choreographers has reached its "institutional" level, so choosing those four characters, as a representation of Indonesian dancer is the right thing to do. With the complexity discipline and body work training, the four dancers and choreographer strengthening on how procession to achieve and advancing body work is located in some important process: exercise, training, and performance. This is different from the process of body works quality and the achievement of most dancers and choreographer outside of Indonesia. Usually the dancers outside of Indonesia only stress on two things: Training and performance. The four dancers in the work have had a typical body works each of them, but it is undeniable that there is a role in the respective Sardono as the maestro. Sardono's strong influence thus again took place in forming a model to the body or body-dance attitude of dancers who then the outcome was, in fact, different from Sardono's works.
\end{abstract}

Keywords: contemporary, embodied, training, rehearsal, performance

\begin{abstract}
ABSTRAK
Penelitian ini membahas empat koreografer, dalam membuka wacana proses ketubuhan penari di Indonesia. Empat koreografer tersebut, Martinus Miroto, Mugiyono Kasido, Hartati, dan Jecko Siompo, memperlihatkan betapa kompleksitas proses ketubuhan mereka berbeda dengan penari dan koreografer pada umumnya, terutama dari luar Indonesia. Mereka memberikan pengalaman yang detail tentang pendisiplinan tubuh mereka untuk mencapai sebuah capaian dan keunggulan. Dengan kompleksitas disiplin dan training ketubuhan, keempat penari dan koreografer ini menggukuhkan betapa proses pencapaian dan kemuktahiran tubuh terletak pada beberapa proses penting: Training, Latihan, dan Pementasan. Jika ditilik secara keseluruhan, keempat penari ini mempunyai pengalaman belajar, atau setidaknya pernah mengalami proses menari bersama Sardono W. Kusumo. Ketubuhan yang yang dieksplorasi adalah ciri khas dari Sardono yang dikenal dengan laku dalam bahasa Jawa. Walaupun belajar dari Sardono, keempat koreografer tersebut mengembangkan tarian yang berbeda dengan Sardono.
\end{abstract}

Kata kunci: kontemporer, ketubuhan, training, latihan, pementasan 


\section{PENDAHULUAN}

Tubuh seniman tari Indonesia memiliki kecerdasan dalam pengaplikasian pada karya mereka. Kepekaan dan kompleksitas tubuh mereka terbukti ketika melakoni proses kreatif karya ke dalam pemahaman tubuh diterapkan pada wacana 'rumah'. 'Rumah' yang dimaksud dalam konteks ini adalah basis pemahaman fisikal ketubuhan seniman, sehingga kompleksitas, dan kepekaannya adalah sebuah laboratorium yang sangat canggih namun alami dan organik. Hal ini berkaitan dengan cara berpikir tubuh penari dan koreografer Indonesia yang tidak lepas dari 'training' ketubuhan mereka dalam bentuk proses latihan yang panjang dan berkesinambungan.

Berbicara tentang tubuh, terdapat beberapa pemikir yang menjadikan spesifikasi tubuh sebagai sebuah wacana utama penelitian mereka, seperti John O'Neill dalam bukunya yang berjudul Five Bodies, pemikiran Giambattista Vico dalam bukunya yang berjudul The New Science (1725), serta pemikiran Freud mengenai bentuk tubuh prostetik 'palsu' manusia dalam bukunya yang berjudul Civilization and its Discontents (1962). Dalam bukunya, O'Neill (2004: 6) menegaskan bahwa, "dalam interaksi antara cara berpikir tentang tubuh adalah tubuh yang berpikir melalui konteks hidup masyarakatnya melaluinya dan kompleksitas keterkaitan ragam bidangnya".

Hal ini menjadi sangat signifikan ketika O'Neill mempertegas tubuh yang berhubungan erat dengan kontekstual masyarakat yang didasarkan pada ragam bidangnya. Seperti halnya para penari Jawa dituntut untuk belajar silat dan gamelan ketika proses pembelajaran tari klasik ditularkan pada generasinya. Bu Bei Madusari adalah empu tari Jawa di pura Mangkunegaran Surakarta yang piawai membuat batik tulis. Selain itu, ia adalah penembang yang secara style atau cengkok mempunyai kekhasan tersendiri (Sardono W. Kusumo, wawancara, 14 Maret 2011). Bertolak dari contoh bu Bei Madusari, hampir semua seniman tari dan koreografer Indonesia selalu berhubungan dan bersinggungan erat dengan bidang seni tradisi lain yang saling terkait. Alhasil pada kenyataannya, pernyataan O'Neill memberikan perspektif yang kuat untuk mendukung 'tesis' tentang bagaimana training ketubuhan penari dan koreografer kontemporer di Indonesia dikaitkan dengan proses training ketubuhan penari dan koreografer yang berada di luar Indonesia.

Tulisan ini membahas empat koreografer tari kontemporer Indonesia, Martinus Miroto, Mugiyono Kasido, Hartati, dan Jecko Siompo, dalam membuka wacana proses ketubuhan penari di Indonesia. Empat koreografer tersebut memperlihatkan betapa kompleksitas proses ketubuhan mereka berbeda dengan penari dan koreografer pada umumnya, terutama dari luar Indonesia. Mereka memberikan pengalaman yang detail tentang pendisiplinan tubuh mereka untuk mencapai sebuah capaian dan keunggulan. Tubuh dari keempat koreografer ini telah mencapai tingkatan "kelembagaan", sehingga pilihan keempat tokoh ini dirasa tepat dalam merepresentasikan tubuh penari Indonesia. Dengan kompleksitas disiplin dan training ketubuhan, keempat penari dan koreografer ini mengukuhkan betapa proses pencapaian dan kemuktahiran tubuh terletak pada beberapa proses penting: Training, Latihan, dan Pementasan. Hal ini sangat berbeda dengan proses ketubuhan dan pencapaian kualitas ketubuhan dari kebanyakan penari dan koregrafer di luar Indonesia. Biasanya para penari di luar Indonesia hanya menekankan pada dua hal: Latihan dan Pementasan.

Sardono W. Kusumo salah satu pionir koreografer tari kontemporer Indonesia menegaskan, di Indonesia praktik kontem- 
porer mempunyai proses yang lebih panjang dan meyakinkan. Hal ini terjadi karena seniman di Indonesia memiliki budaya 'laku' sebelum mereka mencipta karya. Para seniman akan mempelajari dan menguasai nilai dasar dari budaya yang ingin dipertunjukkannya, sebagai contoh: seorang koreografer yang ingin mengangkat tradisi dari tanah Jawa akan belajar menembang, karawitan atau wayang sebagai masukan bagi proses ketubuhan yang dapat menciptakan gerak yang kompleks, luar biasa, dan holistik. Pembelajaran yang mendalam turut melatih sensibility yang tidak berorientasi pada sebuah produk. Melewati proses belajar secara lintas seni akan memperkaya khazanah ketubuhan, memperkaya vocabulary gerak dan ekspresi (Kusumo, 2004: 76). Hal ini menjadi baik, karena dengan adanya pembelajaran akan memunculkan lebih banyak ide yang bisa diterjemahkan ke dalam sebuah koreografi. Elemen-elemen seperti itu yang dibutuhkan seorang koreografer untuk terus dapat berkarya.

Kebanyakan dari koreografer tari kontemporer Indonesia memang berakar pada kebudayaan, dan karya mereka merupakan pembaruan dari tari budaya. Mereka menginterpretasi kembali serta mulai menggali tari dalam ekspresi dan teknik olah tubuh, dan menampilkan koreografi yang tidak pernah keluar dari jati diri keindonesiaan. Di Eropa dan Amerika misalnya, kontemporer yang berarti kekinian merupakan murni ekspresi sang koreografer. Murni dalam arti bentuk penolakan terhadap sistem dan aturan jenis tari sebelumnya, namun bentuknya selalu abstrak dengan narasi yang kuat.

Sementara di Indonesia, Bagong Kussudiardja dan Wisnoe Wardhana membawa istilah kontemporer ke dalam ranah seni tari Indonesia dengan tafsir yang berbeda dengan apa yang dipahami oleh penari-penari Eropa dan Amerika. Indonesia yang kaya dengan kebudayaan justru tidak meninggalkan tradisinya, melainkan mengubah bentuknya menjadi lebih bebas, lebih berekspresi, tanpa meninggalkan pakem-pakem dan teknik-teknik tari tradisi. Tradisi semakin terpelihara walaupun idiom tradisi masuk pada genre tari baru seperti modern dan postmodern.

Tari kontemporer yang kini memperlihatkan proses kreatif dan inovasi yang semakin mendalam menjadi sebuah pijakan yang kuat pada perkembangannya kini. Tari kontemporer dalam keberadaannya kini telah merepresentasikan intra dan trans kultural dalam pembentukan idiom geraknya. Tidak hanya merujuk pada sebuah kebudayaan, setiap penari mempunyai kesempatan dalam mengembangkan dirinya dengan interpretasi dan pemahaman atas kebudayaan lain. Proses ini tidak sematamata dilakukan tanpa sebuah riset yang jeli, namun kini koreografer juga dituntut untuk semakin kritis dan peka terhadap segala bentuk fenomena dan peristiwa budaya.

\section{METODE}

Penelitian tentang empat tokoh tari kontemporer yang terelaborasi ke dalam bentuk perkembangan dan perubahan bentuk serta kreativitas ini, menggunakan metode penelitian kualitatif dengan pendekatan multidisiplin (R.M. Soedarsono, 2001:33-34). Penelitian kualitatif ini diwujudkan secara deskriptif-analitis. Penelitian kualitatif penulis anggap tepat karena jenis pendekatan ini mampu menggambarkan, memaparkan, dan mengkonstruksi pemahaman berdasarkan data yang ada. Pemaparan dan penjelasan kualitatif membutuhkan kompleksitas dan variasi pemahaman. Kompleksitas dari pemahaman akan terhubung dengan pendekatan multidisiplin (Soedarsono, 2001:3334). Kekayaan data akan menghasilkan penelitian yang holistik.

Alhasil, dalam mendapatkan jawaban 
atas rumusan permasalahan yang telah disusun, adapun tahap yang sistematis dalam melakukan penelitian ini, seperti:

1. Pengumpulan Data

Dalam mengumpulkan data, terdapat beberapa usaha yang ditempuh oleh penulis untuk mendukung keperluan penelitian ini. Pengumpulan data dibedakan menjadi:

a. Observasi

Data perubahan dan perkembangan bentuk serta kreativitas dalam tari kontemporer membutuhkan data yang jelas dan pasti, sehingga pengamatan langsung dari peneliti dapat menjadi sumber data yang menarik. Sudah barang tentu jika observasi yang dilakukan penulis memiliki daya interpretasi dan partisipasi yang kuat, terlebih penulis juga berkecimpung dalam ranah praktik tari.

b. Wawancara

Wawancara dengan narasumber turut dilakukan untuk mendapatkan informasi yang jelas mengenai perubahan dan perkembangan yang terjadi. Wawancara menggunakan sistem bebas dan terbuka, sehingga memudahkan narasumber untuk bercerita tanpa tuntutan layaknya wawancara terstruktur. Penulis hanya memberikan pertanyaan umum yang memungkinkan penelusuran jawaban dari narasumber. Wawancara memastikan dan menuntun penulis dalam memaparkan data menjadi sumber yang sahih.

c. Studi Kepustakaan

Studi kepustakaan dapat membantu pemahaman dan pengetahuan terkait data yang sudah tidak memungkinkan untuk didapatkan kembali. Data tertulis ini memberikan data yang penting dalam penulisan disertasi ini. Studi pustaka ini memberikan penulis data tertulis dan rujukan yang dapat membantu proses penelitian ini.

d. Dokumentasi

Selain data lisan dan terulis, dokumentasi diperlukan untuk memberikan data yang lebih jelas dalam disertasi ini. Dalam memecahkan permasalahan yang ada, terlebih teori gerak serta konsep estetis koreografis, dilakukan pendekatan dengan menekankan pentingnya penggunaan perekaman dengan notasi dan audio visual (R.M. Pramutomo, 2002:13).

2. Penentuan Narasumber

Perkembangan dan perubahan membutuhkan data utama dari para narasumber. Narasumber memberikan data yang utama dalam disertasi ini. Dengan demikian, penulis menentukan narasumber yang berdasarkan: kompetensi narasumber; kontinuitas dalam berkarya; karya yang diakui baik di dalam maupun di luar negeri; mewakili sebuah institusi; mempunyai visi dan misi dalam berkarya; mempunyai jiwa idealis dalam berkarya yang tidak hanya didasarkan pada pesanan; meneruskan tari kontemporer Indonesia. Ketentuan yang dibuat ini dilakukan untuk menentukan penari yang serius dan penting untuk generasi ke depan. Narasumber utama dalam penelitian ini adalah: Sardono W. Kusumo, Martinus Miroto, Mugiyono Kasido, Hartai, Jecko Siompo, dan Eko Supriyanto (penulis).

\section{Analisis Data}

Analisis data sangat dibutuhkan dalam disertasi ini. Proses analisis ini dapat memberikan langkah jitu di saat melakukan penelitian. Analisis meyakinkan penulis ketika memilih data yang digunakan dan mereduksi data yang sedemikian banyaknya. Analisis data ini mengantarkan penulis dalam menemukan kenyataan penelitian berupa data, yang dapat digunakan untuk menjawab pertanyaan penelitian. Analisis data membuat penelitian bersifat eksplisit dan holistik.

Proses ini bertujuan untuk mengukuhkan identitas dan signifikansi kehadiran tari kontemporer di Indonesia. Eksistensi kreator tari/kepenarian pelaku tari di Indonesia memasuki ranah seni pertunjukan dalam konteks silang budaya dan kolaborasi, intercultural. Tari dalam cakupan dan 
wacana seni pertunjukan lain seperti; opera kontemporer, drama musikal, seni pop, serta film dan media. Meetode ini memberikan kecermatan pada aspek-aspek artistik yang menunjukan kualitas perkembangan tari kontemporer Indonesia dalam perubahan bentuk gerak, genre, gaya penyajiannya, serta kreativitasnya.

\section{HASIL DAN PEMBAHASAN}

Berikut penjelasan lebih lanjut mengenai tubuh dan proses ketubuhan dari keempat penari dan koreografer kontemporer Indonesia periode 1990-2008:

\section{Martinus Miroto}

Martinus Miroto adalah salah satu penari yang kokoh berpijak pada tradisi Jawa, namun hasratnya tidak terhenti untuk tetap mencari pembaruan-pembaruan dalam karya koreografinya. Salah satu usahanya adalah dengan berguru kepada Bagong Kussudiardja yang memberinya kesempatan untuk mencipta karya "Dora-Sembada" di tahun 1979. Dalam karya ini, Miroto bebas menginterpretasi tradisi menjadi sebuah sajian yang menarik. Pembelajaran dari Bagong nampaknya sangat menginspirasi Miroto dalam gaya koreografi dan teknik geraknya. Tidak hanya itu, Miroto mendapatkan kebebasan dan pengalaman baru yang datang dari luar tubuh, lewat pembelajaran dari Bagong. Keluar dari bingkai klasik Jawa, Miroto memasuki bingkai baru yang juga memiliki batasan-batasan, namun tidak membatasi aspek kreatif dan inovatif dari Miroto dalam menciptakan karya-karya tari kontemporernya.

Setelah itu, Martinus Miroto mempelajari dan meningkatkan improvisasi olah tubuhnya dengan tuntunan Sardono W. Kusumo. Dari pengalaman berimprovisasi tersebut, ia menemukan gaya khas miliknya, dan mulai mencipta gerak ketubuhan berdasarkan ide dan gagasannya sendiri. Miroto menemukan kemungkinan baru dan kebebasan di dalam tubuhnya. Miroto mencoba berdialog dengan tubuhnya, dan mulai memasuki ruang refleksi dan pengalaman ketubuhannya. Refleksi ini menjadikan beberapa karya Miroto bersifat sangat personal, namun karya personal tersebut dapat diterima oleh penikmatnya walaupun tidak mengalami pengalaman yang sama dengan penciptanya.

Salah satu karya unggulan Miroto adalah "Penumbra" pada tahun 1992, yang ia padukan dengan rapi keragaman teknik gerak dan refleksi pengalaman hidupnya. "Penumbra" adalah karya yang diciptakan Miroto sebagai tugas akhir dari Master of Fine Arts (M. F. A.) di University of California Los Angeles, Amerika Serikat. Dalam tari tunggal tersebut, Miroto mengenakan topeng Panji (putra-alus Jawa) dan menari tunggal dengan iringan musik Gabriel Roth yang membawa imaji penonton ke ruang pertunjukan dengan musik Jathilan. Ketukan berulang yang stagnan mengindikasikan kemungkinan mengalami trans; sementara kaki Miroto menjejak berulang, tubuhnya bergerak gemulai dengan tekukan tubuh seperti penari perempuan.

Jejak tarian Jawa yang lembut mendominasi karya Miroto tersebut. Teknik yang ditampilkannya adalah klasik Jawa, namun dengan gagasan koreografi modern yang sangat inovatif. Di bagian akhir dari koreografinya, Miroto melepas dan melakukan dialog dengan topengnya, seakan ia dan topengnya memiliki hubungan yang sangat intim. Unsur-unsur feminisme jelas terlihat dalam karya "Penumbra" tersebut. Miroto memilih feminisme karena sifat-sifat perempuan yang kompleks, dan gejala multipersonality lebih tepat untuk menggambarkan ekspresinya dalam karya "Penumbra" tersebut. Keindahan dan kemarahan pada beberapa bagian dalam karya ini juga terlihat emosional, dan menggambarkan secara kuat keadaan kepribadian perempuan pada umumnya.

Karya "Penumbra" dari Miroto merupa- 
kan refleksi atas jati dirinya sebagai penari kontemporer. "Penumbra" ditarikannya dengan gerak gemulai dan ringan layaknya seseorang yang riang dan tanpa beban, berganti menjadi garang, marah dan agresif, setelah Miroto membuka topeng dan 'berkomunikasi' dengannya. "Dialogi" ini menunjukkan betapa dekat dan akrabnya antara Miroto dan sang topeng. Miroto menyampaikan kasih melalui kelembutan gerak tangan dan langkah yang perlahan. Ia terus tenggelam dalam pencitraannya sebagai perempuan. Koreografinya mendeskripsikan ragam ekspresi dan perasaan yang tercuat dari hati manusia pada umumnya. Rasa sedih, gembira, dan takut, menjadi bagian dari koreografi yang digabungkannya secara bebas. "Penumbra" diciptakan Miroto pada tahun 1995; sejak saat itu "Penumbra" atau "The Shadow of Penumbra" telah berkelana keliling Asia, Eropa, dan Amerika.

Bagi Miroto, berkarya dan mencipta sebuah koreografi adalah hal yang penting, tetapi yang lebih penting lagi adalah karya sebagai terapi diri dalam melihat lebih dalam lagi permasalahan hidup, dan dalam mencari jawaban atas segala pertanyaan dalam hidup, serta obat bagi kekecewaan atau pun luka dalam hidupnya. Karya Miroto bertajuk 'Sampah' di tahun 1986, diciptakan saat ia merasa diperlakukan sebagai Sampah masyarakan oleh lingkungan di sekitarnya. Menata tari bagi Miroto merupakan katarsis, 'penyucian' diri untuk melepas ketegangan hidup. Selain itu, menata tari menjadikan dirinya lebih berarti, karena sudah melakukan sesuatu bagi masyarakat. Selain terapi dan pengakuan diri, yang mendorongnya untuk terus berkarya adalah kesadaran melanjutkan spirit dari guru-gurunya. Dengan begitu, ia merasa sudah memberikan sumbangsih dan turut serta berpartisipasi dalam pengembangan kesenian kepada masyarakat tari dan awam.

Sebagai penari dan penata tari, Miroto pernah tampil dan memberikan workshop di Amerika Serikat, Belanda, Malaysia, Korea Selatan, Taiwan, Australia, Jepang, dan Zimbabwe. Ia turut menerima penghargaan ketika tampil di festival tari internasional seperti: American Dance Festival, Arts Summit Indonesia, Indonesian Dance Festival, dan menerima gelar penari putra-alus Yogyakarta terbaik di tahun 1996. Pentas kolaborasi pun pernah ia lakukan, antara lain dengan YinMei (Amerika Serikat), Nandhini Ninha (India), Garin Nugroho (Indonesia), dan Ong Keng Sen (Singapura).

Miroto mempunyai kiat dalam menjalani profesinya, yaitu sabar, tekun dan bersyukur. Miroto pun bekerja keras atas pilihannya, kerap lupa untuk istirahat pun dilalui demi karya dan ketubuhannya. Hal ini ditegaskannya (Martinus Miroto, wawancara, 14 Maret 2011) sebagai berikut: "Kecuali dalam kondisi capek sekali, barulah saya merebahkan tubuh, tidur. Saya termasuk orang yang tahan tidak tidur. Tiap harinya, rata-rata tidur di atas jam 01.30 dini hari. Beberapa kali, malah nonstop selama 24 jam tidak tidur". Ia berusaha memanfaatkan waktu untuk berbagai aktivitas positif dan menguntungkan. Alhasil, ia lebih mementingkan untuk mengeksplorasi sesuatu.

Tahun 2001 Miroto membangun Studio Tari Banjarmili di tepi sungai Bedog. "Seorang koreografer perlu mempunyai studio tari sendiri agar bisa bebas menempa penarinya seperti yang ia inginkan," ungkap Miroto. Selain itu, Miroto juga memiliki studio sendiri di Kradenan, Banyuraden Gamping. Lewat studionya, ia mulai tertantang untuk membuat program, mencoba mendidik generasi muda, serta berkomitmen untuk mengembangkan seni tari. Sejak 2007, untuk memacu kehidupan tari di kota tempat tinggalnya, setiap tahun ia menyelenggarakan Bedog Arts Festival (Kelola, 2010). Event ini digagas olehnya dan bekerja sama dengan Garin Nugroho, dan G. K. R. Pembayun. Di dalam festival ini, rangkaian kegiatan tidak hanya menampilkan karya- 
karya penari, tetapi juga terdapat workshop, seminar, pasar rakyat, bahkan ada gerakan pemeliharaan sungai Bedog.

Pada tahun 2006, Miroto mendapat kesempatan untuk memerankan tokoh Setyo dalam sebuah film musikal "Opera Jawa" arahan sutradara Garin Nugroho. Film yang mengadaptasi cerita Ramayana ini mengangkat permasalahan cinta segitiga antara Rama, Sinta dan Rahwana. Keikutsertaannya pada film tersebut telah memperluas jaringan kerja serta pengalaman kepenarian, koreografi, dan keaktorannya. Miroto mendapatkan peran yang sangat penting untuk tidak hanya memerankan tokoh Setyo/Rama dalam film ini, namun ia bersama grup tarinya, Banjarmili Studio, juga memberikan konstribusi penting dalam kerjasama dan kolaborasinya bersama Garin Nugroho di film tersebut.

Perpaduan kolaborasi ini menjadi penting bagi sejarah seni pertunjukan Indonesia; dalam hal ini Miroto, Garin dan para pemain lainnya, telah memberikan nafas baru bagi seni pertunjukan Indonesia. Tidak hanya menampilkan sebuah pertunjukan tetapi juga mengangkat permasalahan, mengetengahkan ironi, dan menyodorkan kompleksitas nyata kehidupan kultur Jawa dalam era globalisasi. Tidak hanya dalam ranah gerak dan koreografi, ia mampu mengetengahkan kedalaman tradisi yang sangat luwes dan berbaur dengan zaman, bahkan bersinggungan mesra dengan tatanan eloborasi layar film. Karya ini dibuat untuk memperingati 250 tahun lahirnya komposer Mozart, dan tayangan perdana film ini dipertontonkan di Viena Austria tahun 2006. Miroto dalam praktik tubuh dan tari tidak hanya memberikan sumbangsih pada nilai tari, tetapi juga pengaruhnya pada aspek budaya dan sosial masyarakat.

\section{Mugiyono Kasido}

Berbasis tari tradisi yang dikombinasikan dengan pengalaman tubuh yang luas,
Mugiyono Kasido, pria kelahiran Klaten Jawa Tengah ini tumbuh dari keluarga dalang. Ia telah mengembangkan gaya koreografinya dalam bentuk kontemporer yang khas: lentur, lucu, dan cerdas. Acuan Mugiyono dalam menciptakan sebuah koreografi adalah berbagai aspek kebudayaan tradisional Indonesia, namun tetap menggunakan referensi modern. Mugiyono adalah penari yang awalnya membatasi diri dalam ranah tari Jawa klasik.

Tari Jawa, menurut Mugiyono, tidak hanya dianggap lebih dari sekedar hiburan tradisional, tetapi juga sebagai bentuk pendidikan moral dan ekspresi emosional. Ketika memulai kariernya sebagai koreografer, ia membuat keputusan untuk mulai membuat gayanya sendiri yang unik, modern, dan tidak lagi dibatasi oleh aturan tari tradisional. Ia mengatakan keputusan ini diambil untuk menghasilkan koreografi yang lebih dinamis namun tetap khas 'Mugiyono Kasido', karena tarian tradisional sudah terlalu monoton baginya. Bagi Mugiyono, "tari harus memiliki dialog". Dalam rangka menciptakan dialog tersebut, ia mengambil prinsip tari Jawa klasik yakni dengan memperluas ide-ide dan gagasannya lebih lanjut.

Sebagai contoh, karyanya yang berjudul Srimpi Neyeng, di mana karya tari kontemporer ini adalah bentuk keprihatinannya terhadap klaim Malaysia terhadap beberapa kebudayaan asli Indonesia. Srimpi Neyeng adalah karya tari yang dipadukan dengan unsur pedalangan, seperti dhodhogan, sulukan, janturan, dan garapan. Keadaan-keadaan politik bangsa yang memprihatinkan menjadi inspirasi Mugiyono untuk menciptakan karya tari kontemporer yang satir namun seringkali juga sekaligus komikal.

Mugiyono berkarya sebagai bentuk protes terhadap kondisi politik bangsa, menurutnya, "karena aku adalah seorang penari maka protesnya pun disampaikan melalui gerak tubuh". Tahun 2000, ia menciptakan 
karya yang berjudul Kabar-Kabur, yang ditarikan secara tunggal sebagai media dalam mengkritisi keadaan sosial, ekonomi, dan politik di Indonesia menjelang kejatuhan Orde Baru. Karya yang dipentaskan sebanyak 130 kali di 17 negara ini, telah membawa Mugiyono melanglang buana ke berbagai festival bergengsi seperti Lincoln Center Festival di New York, Kunsten Festival des Arts di Belgia, Goteborg Festival di Swedia, Adelaide Festival di Australia, Hong Kong Arts festival di Hong Kong, In Transit Festival di Jerman, Dancas na Cidade di Portugal, dan Asian Contemporary Dance Now di Jepang.

Dalam karyanya Kabar-Kabur, Mugiyono menggunakan 'tubuh terdistorsi' sebagai metafora. 'Terdistorsi' dapat diartikan sebagai individu yang terdistorsi oleh negaranya sendiri, saat negara dalam kekacauan setelah jatuhnya rezim Suharto. Dengan menggunakan panggung persegi kecil, Mugiyono menggambarkan versi 'tubuh terdistorsi' miliknya; di sini ia berbicara tentang hubungan antara tubuh dan Negara.

Dalam sebuah wawancara Mugiyono menyatakan (Mugiyono Kasido, wawancara, 14 Maret 2012) sebagai berikut: "Sebuah negara adalah seperti tubuh kita, memiliki beberapa elemen, yang memiliki fungsi dan posisi mereka sendiri. Mereka harus disimpan dalam harmoni, sebaliknya tubuh akan salah, sakit, dan pada mati dalam kesengsaraan". Dengan Kabar-Kabur (Rumours), Mugiyono membuktikan bahwa seorang penari solo mampu menciptakan kharisma yang menghipnotis sepanjang pertunjukannya.

Di dalam karyanya, ia hanya menggunakan $t$-shirt putih dan celana pendek warna coklat muda. Dalam gelap, langkah lelaki kurus bergerak lambat melintasi panggung ke panggung. Sikap Jawa klasik dipadankan dengan gerak-gerak mengejutkan dalam mempermainkan $t$-shirt, seakan t-shirt itu adalah musuh yang sedang diolok-olok. Ada bagian saat Mugiyono terselubung dalam kain putih dan bergoyang-goyang di dalam- nya, menyerupai karya awal Martha Graham solo, yang berjudul Lamentation (1930).

Permainan emosi yang intens antara humor konyol, ketenangan, dan sikap-sikap seperti mengejek dalam karya KabarKabur menjadikannya sebuah karya yang sulit untuk dijabarkan, namun anehnya sangat memuaskan. Usaha Mugiyono dalam mengangkat seni tari kontemporer Indonesia adalah dengan menciptakan karya-karya dan rutin melestarikan pengetahuan tentang akar serta praktik seni tradisional. Ia ingin membuktikan bahwa walaupun berkomitmen dengan pemikiran tradisional, tetapi tetap mampu menciptakan karya yang bersifat kekinian. Sejauh ini banyak pemerhati melihat gerak-gerak Mugiyono saat menari merupakan paduan antara komedi, tragedi, satir dan ekspresi dramatis serta vokalisasi suara manusia yang mendalam. Demikian juga dengan pentas Kabar-Kabur, yang menggambarkan tentang situasi rusuh Mei ‘98, hingga tarian Srimpi Neyeng yang tercipta karena kegundahannya atas situasi saling klaim kebudayaan antara Malaysia dan Indonesia.

Karya-karya Mugiyono berangkat dari pergulatan hatinya untuk merespons berbagai peristiwa politik. Walau karyanya sarat dengan makna, Mugiyono terkenal dengan karya-karyanya yang mengusung kesederhanaan. Ia adalah pendiri grup tari profesional Mugi, yang merupakan komunitas pertunjukan seni. Institusi ini didirikan atas inisiatif orang-orang yang berasal dari berbagai disiplin dan latar belakang yang bermacam-macam, seperti koreografer, penari, aktor, musisi, dalang, artis pertunjukan, dan juga desainer.

Grup tari profesional Mugi didirikan dengan tujuan untuk dapat meningkatkan pertunjukan kesenian Jawa tradisional dan seni kontemporer Indonesia. Grup ini mengkreasikan tari kontemporer berdasarkan seni Jawa tradisional yang dibentuk dari ekspresi kepribadian. Nama Mugiyono 
Kasido mulai berkibar sejak mengikuti IDF 1993, dan sejak saat itu, ia telah empat kali tampil di forum bergengsi tersebut di tahun 1993, 1996, 2002, dan 2006. Pada tahun 1995, ia bersama Slamet Gundono dan dua penari putri mengikuti ChangMu International Dance Festival di Seoul, Korea Selatan. Keberhasilannya berbuah manis, ia kembali diundang ke ChangMu tahun 1999. Mugiyono juga pernah menjadi asisten peneliti Alessandra Lopes Royo Iyer, dosen senior Departemen Tari di University of Surrey Roehamton, Inggris. Bersama Alessandra ia membantu penelitian terkait arkeologi dan keberadaan relief candi Prambanan serta hubungannya dengan tari Jawa.

Mugiyono banyak menginterpretasikan kembali tokoh atau cerita wayang yang senada dengan selera masa kini. Seperti dalam Surat Shinta (2002), sebuah kolaborasi (Mask Dance Symbiosa Project) dengan penari topeng tradisi (Wangi Indriya) dari Indramayu dan penari topeng Thailand (Boy Hanarong). Dalam karya Surat Shinta, Mugiyono menggugat hegemoni kaum lelaki dengan mengambil kisah kepahlawanan Ramayana. Dalam karya ini, Shinta yang seharusnya membakar diri untuk membuktikan kesuciannya, oleh Mugiyono dibiarkan pergi dengan meninggalkan sepucuk surat untuk direnungkan.

Menurut Mugiyono, perkembangan dunia tari kontemporer di Indonesia saat ini begitu pesat. Ia melihat banyak penari dan koreografer tari menghasilkan karya yang bagus. Namun ia belum melihat dari mereka yang secara total dikatakan sebagai pencipta. Kebanyakan penari atau penata tari belum berani menjadikan tari sebagai profesi, sehingga masih terkesan setengahsetengah dalam pencapaian dan kualitasnya. Terkadang mereka terpaksa tunduk dengan tekanan kebutuhan dan menari, atau mencipta hanya untuk selera pasar saja. Terlihat pada kebanyakan penari di Jakarta yang masuk dalam industri televisi dan se- lebrita. Mugiyono menyatakan (Mugiyono, wawancara, 21 Juni 2011) sebagai berikut: "Banyak penari muda yang berbakat untuk mencipta, tapi tak banyak yang total dan punya keberanian untuk hidup hanya demi dan dari tari".

\section{Hartati}

Hartati adalah seorang penata tari kontemporer senior yang mempunyai tradisi Minang di dalam ketubuhannya. Hal ini terwujud dalam setiap karyanya yang terdapat sentuhan gerak khas Minang. Walau kini Hartati mencipta tari yang lebih kontemporer, tetapi alasannya adalah ketidakinginannya atas kesenian tradisi yang tergerus oleh modernisasi yang semakin hari semakin merajalela di ranah seni tari kontemporer Indonesia. Hartati dengan kepiawaiannya melebur silat dan tarian Minangkabau, mampu bersinergi untuk terus berkreasi melintas batas-batas ragam gerak dan substansi Minang ke ranah kekinian.

Di Indonesia, tradisi dan modernisasi sering dipertentangkan dan diperbincangkan, atau bahkan sering kali terjadi pembandingan antara keduanya. Namun, karya Hartati patut diperhitungkan karena dengan indahnya telah mempertemukan keduanya. Koreografinya yang didasari dengan sifat keterbukaan, memberikan warna baru dalam kancah seni tari. Hartati berkomitmen untuk menyerap, bukan menolak materi modern demi memperkaya unsur tradisi.

Hartati senang bekerja sama dengan teman yang berbeda profesi dengan dirinya. Hal ini dilakukan karena menurutnya akan menambah khasanah daya cipta gerak tarinya. Hal tersebut pula yang menjadikan Hartati sensitif menangkap gejala sosial. Hartati memberikan sumbangsih kepada masyarakat dengan menggarap karya yang mengangkat kegelisahannya terhadap kenyataan sekitar. Kepekaan sosial ini kemudian disempurnakan dengan terus mengeksplorasi teknik geraknya. Ia termasuk koreografer 
yang sangat percaya pada kemampuan gerak dalam berbicara. Penguasaan teknik secara total merupakan syarat mutlak bagi seorang penari. Baginya, seorang penari yang baik harus mampu berbicara, menyuarakan inspirasinya lewat gerak tubuh, dari ujung rambut di kepala sampai dengan ujung kaki harus mampu berdialog antara satu dan yang lain, untuk mendialogkan kegundahan hati.

Sebagai koreografer dari Minang, Hartati dikenal memiliki ciri gerak-gerak tradisi Minang, seperti pencak silat dan randai. Kemampuan itu diasahnya sewaktu bergabung dengan kelompok tari Gumarang Sakti pimpinan Gusmiati Suid (almarhumah). Di kelompok inilah, Hartati belajar banyak tentang idiom gerak, dasar koreografi, dan keterlibatan tradisi sebagai kekuatan tari kontemporer Indonesia. Ia kemudian menjadi generasi penerus setelah Hoeriah Adam, Sofiani, dan Gusmiati Suid, nama-nama koreografer wanita dari Minang yang menjadi pelopor tari kontemporer di Indonesia.

Karya pertamanya sebagai koreografer Gumarang Sakti, yang berjudul 'Suap', dipentaskan di Gedung Kesenian Jakarta tahun 1997. Selanjutnya 'Sayap yang Patah', di pentaskan di Gedung Kesenian Jakarta tahun 2000. Tahun 2002, Hartati mendapat Hibah Kelola untuk karya 'Membaca Meja'. Masih di tahun yang sama, ia menjadi salah satu koreografer Pembukaan Esplanade Singapura (Theatre on the Bay).

Gagasan-gagasan Hartati dalam bentuk karya koreografi mendapatkan apresiasi dari berbagai pihak, sehingga mengantarkannya untuk berkiprah di panggung nasional maupun internasional. Sepanjang kiprahnya di dunia tari, ia telah tampil di berbagai negara di dunia, seperti Singapura, Tiongkok, Kolombia, Amerika, Australia, dan lain-lain. Hartati adalah salah satu dari lima orang koreografer yang digandeng untuk menampilkan karyanya pada SEA GAMES XXVI tahun 2011 di Palembang, Sumatera Selatan.
Koreografinya pada acara akbar tersebut salah satunya menceritakan tentang sejarah sungai Musi.

Sebelumnya di tahun 2010, Hartati berkesempatan menjadi koreografer drama musikal dari 'Laskar Pelangi'. Karya yang berorientasi dari film layar lebar 'Laskar Pelangi' garapan sutradara Riri Reza dan Mira Lesmana ini, sekali lagi menempatkan Hartati pada posisi satu dari koreografer muda Indonesia yang selalu membuka diri dan tidak menutup kemungkinan memasuki ranah seni populer dan industri. Walau banyak yang meragukan kehadiran hasil kreatifnya, Hartati tidak merasa malu atau ragu-ragu melakukan proses kerja ini secara profesional.

Soedarsono dalam tulisannya di buku Umar Kayam dan Jaringan Semiotik me-negaskan bahwa,

Apapun hasil karya seni yang dilakoni secara serius dan profesional, akan menghasilkan sebuah karya seni yang akan diingat selalu oleh penikmatnya. Walaupun karya seni itu ujung-ujungnya adalah sebuah karya "pesanan atau dalam rangka" dari seseorang atau lembaga. Karena seni manapun dan sejak kapanpun selalu berkaitan dengan orang banyak (1998:225).

Toleransi dan keterbukaan Hartati adalah benar seperti diungkapkan Soedarsono sebagai sebuah kerja yang positif (1998: 225). Pada hakikatnya kerja kesenian bersifat kolektif dan tidak akan bisa berdiri sendiri. Hartati yang mendapatkan mandat dari sang sutradara untuk menggarap garapan musikal ini tentunya menjadi wacana yang tidak lazim di zonanya. Ada kaitan antara industri dan popularitas ketika direktur musik dari karya ini adalah seorang musisi berlatar belakang industri populer.

Hartati sangat mengagumi Gusmiati Suid, yang tidak lain adalah ibu mertuanya sendiri. Menurutnya, Gusmiati Suid adalah koreografer handal yang sudah sejajar dengan koreografer-koreografer tingkat dunia 
lainnya. Gusmiati Suid memiliki kharisma kepemimpinan yang sangat kuat. Sikap disiplin dan totalitas dalam setiap proses penciptaannya selalu melibatkan training ketubuhan yang fokus dan terus menerus. Bersama sanggar tari yang dibangunnya, 'Gumarang Sakti', Suid terus mendidik dan menempa para penarinya untuk melihat, memperdalam, dan melakoni filsafat hidup Minangkabau, terlebih bersinergi dengan kehidupan yang kini ada dalam ruang metropolitan Jakarta. Ia secara tersirat menyatakan adanya transformasi proses ketubuhan Minangkabau dan metropolitan yang berkolaborasi. Dari Gusmiati Suid, Hartati memahami Minangkabau sebagai sebuah akar dan sumber dalam berkarya. Suid juga yang memberi pengaruh dan dorongan terbesar untuk Hartati dalam melihat kebudayaan Minangkabau dari sisi yang berbeda dan menafsirkannya kembali dalam manifestasi karyanya (Hartati, wawancara, 14 Maret 2011).

Bahasan dan training ketubuhan Hartati yang mengalami perubahan penting dalam proses kreatifnya adalah ketika sebuah ranah asli yang berada di Minangkabau tempatnya berasal, kemudian hidup dan menghidupi proses ketubuhan ini di ranah dan ruang yang berbeda, yaitu di Jakarta. Konteks tubuh yang melakukan traveling dan menjadi diaspora dalam ruang dan waktu yang berbeda semakin dirasakan Suid dan generasinya, termasuk Hartati. Hal ini terus dilakukan untuk menjadikannya sebuah training ketubuhan yang terus menerus dan tiada henti, untuk tetap menjadikannya muara ide dan meletakkannya sebagai pondasi penting dalam statement kreatifnya.

Alhasil, terdapat artian yang lebih pada tari kontemporer itu sendiri. Menurut Hartati:

Tari kontemporer adalah tari yang berangkat atas cara berpikir, konsep, ide dan gagasan yang mencerminkan aktualitas serta kekini- an. Keseharian yang dialami atau tradisi yang didapat menjadi nafas, roh, dan spirit karya, yang bukan hanya sekedar bentuk. Karena ini yang akan menunjukkan identitas tari kontemporer Indonesia. Pengalaman sebagai koreografer pada Musikal Laskar Pelangi dan Pembukaan Sea Games, dijadikan Hartati sebagai kesempatan baik untuk memperlihatkan bahwa dunia tari tidak hanya sampai di tradisi saja atau yang selalu dilihat di TV. Dunia tari dapat setara dengan bidang seni yang lain, baik di dunia industri maupun di dalam dunia pendidikan. Tari adalah bagian penting yang tidak dapat diabaikan begitu saja. Dunia tari juga sangat terbuka terhadap kemajuan teknologi. Koreografi tidak hanya sebatas eksplorasi gerak lalu merangkainya. Tapi tari adalah sebuah ekspresi yang mampu menyesuaikan diri dengan kemajuan zaman. Sehingga pendidikan/ilmu tari menjadi penting untuk dipelajari".

Pihak-pihak yang juga sangat berpengaruh dan memberikan sumbangsih bagi karier Hartati adalah Sardono W. Kusumo. Ia adalah salah satu orang yang mengarahkan Hartati untuk melihat Silat Minang sebagai salah satu pilihan sumber inspirasi yang dapat digarap dengan baik dan diberikan pendekatan kontemporer melalui kreativitas Hartati. Sardono juga membuat Hartati memandang Silat Minang dari perspektif yang berbeda dari para penari pendahulunya. Selain itu, Institut Kesenian Jakarta (IKJ) tempat Hartati menimba ilmu kepenariannya, merupakan institusi yang juga berperan besar pada kariernya. Di IKJ Hartati mempelajari semua yang dibutuhkan untuk menjadi penari yang berwawasan dan mampu menjadi koreografer.

Kekhawatiran Hartati terhadap terhentinya regenerasi koreografer tari kontemporer disampaikannya dalam sesi wawancara dengan penulis (Hartati, wawancara, 14 Maret 2011) sebagai berikut:

Generasi penari sekarang kurang terprovokasi seperti pada masa saya dulu. Peran Sardono dan Sal Murgiyanto generasi penari setingkat saya sangat menentukan bagi keberlangsungan seni tari Kontemporer Indo- 
nesia. Keaktifan Sardono dan Sal Murgiyanto dalam mempromosikan dan memberikan peluang bagi para penari dan koreografer untuk berkarya seperti dengan diselenggarakannya Indonesian Dance Festival (IDF) sangat berhasil dalam menumbuhkan minat koreografer-koreografer muda pada masa itu.

Mengenai arti sebenarnya tari kontemporer di Indonesia, Hartati berpandangan bahwa sesungguhnya kita harus memberikan perspektif tari tradisi Indonesia kepada orang luar. Tidak hanya mengatakan Indonesia kaya, tetapi juga menjelaskan bahwa tubuh kita masih mempengaruhi cara berpikir kita. Tidak terdapat rongga dan jurang pemisah di antara keduanya. Berbeda sekali dengan orang Barat. Mereka tidak mempunyai masalah dengan tubuh secara harfiah, sehingga mereka dapat menguatkan konsep di kepala mereka dengan mudah. Mengutip Hartati terkait tari kontemporer Indonesa: "didukung oleh teknologi, tidak ada beban tradisi dan sebagainya, namun terdapat rongga di antara keduanya." (Hartati, wawancara, 1 Desember 2014).

\section{Jecko Siompo}

Lahir pada tahun 1975 di Jayapura, Papua, penari dan koreografer Jeck Kurniawan Siompo Pui yang lebih dikenal sebagai Jecko Siompo, adalah salah satu penari yang juga sedang naik daun dalam dunia tari kontemporer di Indonesia. Seperti sebagian besar tari kontemporer Indonesia yang sudah merangkai eksistensinya selama beberapa dekade terakhir, tradisi tari lokal yang kaya akan budaya adalah pengaruh terkuat bagi Jecko dalam mencipta. Menari sepertinya sudah mendarah daging baginya. Tumbuh dewasa, ia tinggal di berbagai daerah di Papua (Irian Jaya): pedalaman Wamena, pesisir Fak-Fak (kampung halamannya), dan ibukota provinsi Jayapura. Hal ini membuat Jecko menguasai banyak jenis tarian dari kampung halamannya tersebut.

Selain itu, ia juga menguasai tarian etnis
Jawa, Sumatera, dan Minang. Saat tercatat sebagai mahasiswa Institut Kesenian Jakarta, Jecko mulai mendalami balet dan tarian jalanan atau street dance, namun ia tidak meninggalkan akar budayanya. Pada tahun 1999, ia menekuni hip-hop di New York. Sementara itu di tahun yang sama, Jecko juga di undang ke Bates Dance Festival di Portland (Amerika Serikat). Sejak itulah Jecko menjadikan street dance sebagai bagian dari koreografi yang diciptakannya.

Sebagai seorang penari, ia telah berpartisipasi dalam produksi bersama dua seniman besar Indonesia yang terkenal, yaitu Sardono W. Kusumo dan Boi G. Sakti. Tidak hanya itu, ia juga berkolaborasi dengan koreografer internasional seperti Peter Chin (Kanada). Karya-karya Jecko yang terkenal antara lain adalah: 'Goda' (1997), 'Ini Budi' (1997), 'Irian Zoom In' (1998), 'Asmat Dani' (1999), 'Obahorok, Buto Huruf (2000), 'Unanuk' (2001), 'Tikus-Tikus' (2003), 'Di KAMAR Kost Aku Mengganti Baju' (2004), 'Di Depan Papua' (2005), dan 'Terima Kos' (2007). Pada tahun 2002, ia dianugerahi beasiswa oleh Goethe-Institut untuk belajar teater tari di Jerman. Jecko juga telah berpartisipasi dalam forum tari dan festival seni internasional, baik di Indonesia maupun di Asia, Eropa, dan Amerika Serikat. Jecko pun turut berpartisipasi pada 'Hidup Seni Bangkok' (2007), 'Asia Contemporary Dance Festival' di Osaka (2007, 2008), 'Konferensi Asia Dance' di Tokyo (2007), dan 'Festival Seni Hong Kong' (2009).

Jecko adalah pencetus dari gerakan Animal Pop. Ia, yang pada tahun pertamanya kuliah di IKJ, telah terlibat sebagai penari dalam showcase Indonesia Dance Festival dengan Koreografer Peter Chin dari Kanada. Hal ini merupakan penghargaan sebagai koreografer terbaik dalam Lomba Koreografi Gedung Kesenian Jakarta pada kategori kontemporer dengan karya 'Goda'. Pada tahun itu pula karya 'Goda' dan 'Ini Budi' dipentaskan di Teater Utan Kayu, Jakarta 
(Jecko Siompo, wawancara, 14 Maret 2011).

Dikatakannya lebih lanjut,

Seni tari di Indonesia baginya adalah yang terbaik di dunia. Tarian dari Aceh hingga Merauke itu adalah gerakan yang tidak ada di negara mana pun di dunia. Jecko mengambil contoh Indonesia karena menurutnya, Indonesia sudah sangat komplet dan lengkap dari gerakan berdiri hingga gerakan melompat. Masing-masing daerah memiliki gerakan masing-masing beserta prinsipprinsipnya. Jika menilik dunia, balet hanya mempunyai satu, sedangkan di Indonesia tidak terbatas pada tarian yang principal.

Jecko selalu menganggap bahwa akar dari seluruh tarian di dunia berasal dari Papua. Begitu bangganya ia pada tanah kelahirannya, beberapa dari karyanya adalah mengangkat tentang tanah kelahirannya tersebut. Karya tentang tanah kelahirannya tertuang pada karya 'Yang di depan dan Yang Di Belakang' dan 'Irian Zoom In'. Karya yang terakhir ini ditampilkan pada sebuah festival di bulan November 1998 yang berlokasi di Taman Ismail Marzuki. Jecko mementaskan karyanya yang berjudul 'Asmat Dani' dan karya koreografi 'Obahorok' yang dipentaskan di Graha Bhakti Budaya Taman Ismail Marzuki pada tahun 1999. Jecko melanglang buana dari tahun ke tahun, mengembara mencari identitas 'animalistiknya' ke dalam ranah tari kontemporer Indonesia.

Ketika Jecko mempelajari tarian dari tradisi budaya yang sama sekali berbeda dengan budaya tanah kelahirannya, seperti tradisi Jawa atau tarian Minang, hal tersebut memperkaya ketubuhan Jecko dalam mencipta tarian dari tradisi kebudayaan Papua. Pendekatan Jecko terhadap tarian daerah lain memperkuat daya ciptanya, dan menurutnya, mempelajari budaya lain meluaskan wawasannya saat menciptakan koreografi karya-karyanya sendiri (Jecko Siompo, wawancara, 3 Desember 2014). Tarian tradisi, menurut Jecko, adalah:

Semuanya sama dilihat dari sisi nilai kedisiplinannya dan prinsipnya. Hanya bahasa dan makanan yang dikonsumsi masyarakat dari kebudayaan yang berbeda yang menyebabkan tarian tradisi memiliki kekhasan tersendiri dari masing-masing suku.Tarian tradisi juga adalah inspirasi terbesar Jecko dalam menciptakan genre Animal Pop.

Animal Pop, genre yang diciptakan Jecko, menurutnya adalah fusi dari primitivism dengan modernisasi. Tertera pada karya Jecko Di Depan Papua, Animal Pop milik Jecko membawa energi dan semacam kesenangan yang orisinal dan spontan. Jecko menjadikan $D i$ Depan Papua menjadi salah satu karya yang sangat mudah untuk dinikmati dan dicerna. Papua, dimulai dari zaman batu, ditafsirkan secara eksentrik. Tiruan gerakan binatang/ kera dengan sentuhan hip hop adalah penghiburan tersendiri. Karyanya memancarkan tingkat kreativitas yang tinggi dan menghibur. Sampai hari ini Animal Pop meluas menjadi sebuah komunitas, bahkan menjadi institusi yang menaungi penggemar hip-hop di Indonesia.

Animal Pop digemari mulai dari usia anak-anak hingga dewasa. Komunitas ini juga menyelenggarakan kompetisi untuk mengukur kemampuan dan ajang berkumpulnya para pecinta hip-hop di Indonesia. Animal Pop sebagai agency yang berhasil menaungi komunitas hip-hop berperan memelihara keberlangsungan seni tari hiphop di bawah asuhan Jecko ini.

Menurut Jecko, tarian papua adalah embrio dari segala tari di dunia; ia yakin setelah melihat bagaimana tarian jenis hip-hop dan street dance yang berkembang di Amerika memiliki dasar-dasar gerakan dari Papua. Karya Jecko selalu terinspirasi dari tarian asal Papua, "bukan kolaborasi, hanya mengambil idenya saja", begitu menurutnya. Karya-karyanya terinspirasi dari kehidupannya sehari-hari, yaitu kebiasaan dan interaksi sosial yang ia alami setiap hari di tanah kelahirannya. 'We Came from the East' adalah karya Jecko paling mutakhir tentang manusia pertama yang ada di dunia dan proses 
pertumbuhannya. Sekali lagi karya ini menyampaikan keyakinannya bahwa segala akar budaya termasuk tari yang ada di seluruh dunia berasal dari Papua (Jecko Siompo, wawancara, 14 Maret 2011).

'We Came from the East' adalah salah satu karya Jecko yang telah melanglang buana di dalam maupun di luar negeri. Saat ditampilkan di Malthouse Theatre, Melbourne, Australia, karya ini membuat banyak orang heran. Jecko yang mengklaim hip-hop sebagai tarian asli dari Papua, mencoba menggambarkan hubungan antara tari tradisional Papua dan hip-hop kontemporer, dengan vokabuler teknik mulai dari yang terkesan sudah kuno hingga gerakan animalistik khas Jecko yang sudah terkenal di pertunjukan.

Hip-hop adalah tarian yang menggambarkan inspirasi tari dari seluruh dunia. Jenis tarian ini pada masa tertentu ditarikan sebagai ekspresi bagi kaum yang kurang beruntung secara materi yang tinggal di Amerika atau Eropa untuk mengintegrasikan kebudayaan asli mereka dengan kebudayaan barat. Perhatian surat kabar pun terhipnotis dari tari Jecko; Harian The Strait Times dari Singapura menggambarkan karya Jecko ini sebagai "kekuatan yang patut diperhitungkan," sementara Jakarta Globe menyatakan "pada akhirnya panggung menjadi buram oleh banyaknya gerakan berputar, badanbadan yang berputar dengan sangat cepat dan indah".

Pernyataan Jecko bahwa "Indonesia lah tempat semua tarian di dunia berakar", telah menjadi kontroversi tetapi membawa nilai tersendiri yang membuat praktisi tari memulai riset mereka. Kritik tajam maupun pujian yang datang dari segala penjuru festival untuk karya Jecko yang secara gambling menggambarkan pernyataannya. 'We Came from the East' merupakan karya Jecko yang menampilkan keindahan serta kepolosan kebudayaan Papua. Beberapa orang berpendapat bahwa pernyataan Jecko itu konyol, bahkan pemilihan musik pada pe- mentasan 'We Came from the East' sama sekali tidak merepresentasikan hip-hop; lalu karya yang menampilkan penari dengan mengenakan kostum minim semacam bikini juga menciptakan opini yang melekat tentang tarian Asia, Indonesia khususnya, yang selalu dipandang eksotis oleh sebagian orang.

Jecko memiliki pendapat sendiri tentang koreografi seperti yang tercantum dalam statement pribadinya (Jecko Siompo, wawancara, 3 Desember 2014) sebagai berikut:

Choreography is human movement and formed a dance. There are three forms of the stage. The first is a traditional stage. The second is to create a traditional stage. The third is the entertainment stage. When the first stage and second stage are combined, then it is contemporary dance. The third stage is the stage of entertainment and for those who wants in to be cheered. And at the same time that there is a third stage in a traditional Indonesian dance in a different time. The third stage when we combine all the things above and that is contemporary stage of particular interest. So for my contemporary dance is the imagination of a development life of the dance itself.

Bagaimanapun, 'We Came from the East' adalah salah satu karya koreografer asli Indonesia yang patut diperhitungkan karena ekspresi yang ditampilkan penuh keyakinan dan kebanggaan terhadap tradisi asli Indonesia. Selain itu karyanya menciptakan kesadaran mengenai betapa kayanya Indonesia, baik dari kebudayaan maupun alamnya.

Statement yang sedikit dipaksakan ini memberikan kesan betapa Animal Pop dan proses ketubuhan Jecko sangatlah 'liar'. Keliarannya sangat erat dengan empathy riset Jecko dalam penemuannya dengan Animal Pop. Proses kreatif secara non-humanis memberikan wacana baru dalam mengambil posisi tari kontemporer Indonesia ke depan, dengan segala kompleksitas ragam serta keterbatasannya. Pada akhirnya wacana kantong kesenian Indonesia juga bertambah dengan kehadiran Jecko yang mewakili Papua dan Indonesia Timur. Kehadiran Jecko seakan memberikan alternatif tari yang tidak 
lagi mengacu hanya pada budaya keraton yang banyak didominasi oleh koreograferkoreografer dari Jawa dan Sumatra.

Bagaimanapun yang dilakukan oleh koreografer Indonesia, termasuk Jecko dalam berkarya, adalah cara melakukan penghormatan terhadap tradisi. Upaya mengagungkan kebudayaan Indonesia dapat dilihat karena di dalam setiap karya koreografer tetap merujuk dan menegaskan makna budayanya (Murgiyanto, 2008: 120), yang oleh Sal Murgiyanto dinyatakan, bahwa:

\begin{abstract}
Makna adalah unsur yang dipandang penting dalam sebuah karya tari. Cara mendapatkan makna sebuah karya tari adalah jika penilaian teknik dapat dipahami dari menganalisis 'teks' atau pertunjukan dan koreografi tarian, maka makna sebuah karya tari dapat diperoleh dengan mengamati 'konteks' atau kaitannya dalam budaya, sosial, ekonomi, politik, agama, dan sebagainya.
\end{abstract}

Jika ditilik secara keseluruhan, keempat penari ini mempunyai pengalaman belajar, atau setidaknya pernah mengalami proses menari bersama Sardono W. Kusumo. Ketubuhan yang yang dieksplorasi adalah ciri khas dari Sardono yang dikenal dengan nglaku dalam bahasa Jawa. Eksplorasi ketubuhan secara kompleks memperkaya intuisi dengan mencari kembali kesadaran tubuh lewat alam dan mengasah kepekaan terhadap hal-hal yang terjadi di sekitar. Ritual untuk tubuh yang sering dilakukan Sardono menuntun penari melakukan reproduksi tubuh dan memperkuat integrasi tubuh terhadap teknik. Nglaku sebagai satu proses yang dilakukan oleh penari Indonesia tidak dilakukan oleh penari dari Amerika dan Eropa. Penari Indonesia yang dipelopori oleh Sardono, pada proses ketubuhan memang sangat mengagungkan reaksi tubuh yang alami yang dihasilkan dari pengembaraan kultur (Jecko Siompo, wawancara, 14 Maret 2011).

Menurut Jecko Siompo, Sardono dan juga IKJ adalah, bahwa eksplorasi menjadi inspirasi yang sangat penting dalam dunia tari. Artinya pada Sardono yang notabene guru besar di IKJ, terdapat perbedaan dan variasi tradisi ketika kita ingin mempelajari tari di sebuah sekolah. Sebab setiap pelajar atau setiap penari belajar untuk memahami perkembangan sebuah tari. Jecko berpendapat bahwa tidak semua orang punya kepedulian terhadap tradisinya masing-masing, atau tidak semua orang punya imajinasi yang sama melihat tarian sebagai tradisi. Sebagai seorang 'seniman', ia harus mempunyai kepedulian yang lebih. Alasan Jecko menganggap bahwa Indonesia adalah 'dunia' karena di Indonesia terdapat begitu banyak tradisi yang mampu dibanggakan (Jecko Siompo, wawancara, 3 Desember 2014).

\section{PENUTUP}

Keempat penari dalam karya-karyanya telah mempunyai kekhasan tersendiri dalam ketubuhannya masing-masing, namun memang tidak dapat dipungkiri bahwa terdapat peran Sardono di masing-masing penari tersebut. Keempat penari tersebut mengangkat tradisi menjadi sebuah seni pertunjukan yang pantas dipuji dan dipertunjukkan kembali. Pengaruh kuat Sardono justru kembali berlangsung dalam model olah tubuh atau sikap tubuh-tari dari penaripenari yang pernah terlibat dalam proyekproyek tari Sardono.

Sardono membawa para penari ke tingkat lebih lanjut dan mendorong mereka untuk selalu melihat seni tari dari sudut pandang yang diinginkan oleh penari itu sendiri. Sardono selalu menekankan pentingnya penelitian terhadap tradisi bagi ilmu kepenarian. Ketubuhan bagi Sardono adalah sesuatu yang membutuhkan eksplorasi dalam ilmu kepenarian. Ilmu yang diberikan pada institusi akan lebih terasah dengan mendalami kebudayaan dan tradisi. Hartati 
dan Jecko sama-sama menganggap cara Sardono mengajarkan ilmu tari dan ketubuhan telah memberikan perspektif yang berbeda, dan membantu mereka menentukan pilihan ciri dalam berkarya.

Mugiyono Kasido merupakan fenomena lain yang layak dicermati. Ia banyak mencipta untuk dirinya sendiri, dibawakan oleh dirinya sendiri secara tunggal, terkadang berkolaborasi dengan penari atau seniman dari disiplin seni yang berbeda. Mugiyono tetap berusaha mengubah tradisi yang dialaminya menjadi sebuah wadah transfer personal dari pengalaman dan perasaannya. Ia bergulat untuk mengolah ketubuhan kekiniannya yang berjalan dengan tradisi sebagai cirinya.

Dengan kemampuan teknik yang dipunyainya, tidak jarang kemudian pertunjukan-pertunjukan Mugiyono menjadi terlihat serupa, walau dia bekerja dengan tema berbeda. Meskipun tradisi masih menjadi bagian dalam tarinya, ketubuhan dengan teknik tinggi seperti yang dimilikinya terlihat seperti mengalami kesulitan dalam melakukan pendekatan personifikasi terhadap tema-tema lain yang diangkat. Kedekatan seorang seniman tari dengan teknik yang dimilikinya sendiri, memang cenderung membuat bahasa yang sama, seperti yang dilakukan oleh Mugiyono Kasido.

\section{Daftar Pustaka}

O'Neill, John

2004 Five Bodies: Re-Figuring Relationship. Canada: Sage Publication

R.M. Pramutomo

2002 'Etnokoreologi'. (Yogyakarta; Majalah Gong edisi 40/2002), 13.

R. M. Soedarsono

1998 “Umar Kayam dan 'Seni dalam Rangka'", dalam Umar Kayam dan Jaringan Semiotik, Aprinus Salam, ed. Yogyakarta: Pustaka Pelajar

2001 Metode penelitian Seni Pertunjukan dan Seni Rupa. Bandung: Masyarakat Seni Pertunjukan Indonesia

Sal Murgiyanto

2008 Menulis Kritik Seni dalam Krisis Kritik, Seperempat Abad Pasca Gendhon Humardani. Surakarta: ISI Press

Sardono W. Kusumo

2004 Hanuman, Tarzan, Homo Erectus. Jakarta: Penerbit ku/bu/ku. 